\title{
Ability of arbuscular mycorrhiza to promote growth of maize plant and enzymatic activity of an alluvial soil
}

\author{
Mahendra Singh*, Kasturikasen Beura, Amit Kumar Pradhan, Rajiv Rakhit, Manohar Lal \\ Department of Soil Science \& Agricultural Chemistry, Bihar Agricultural University, Sabour, Bhagalpur-81321, INDIA \\ *Corresponding author. E-mail: mahendra_saini_soil@yahoo.com
}

Received: April 26, 2015; Revised received: October 15, 2015; Accepted: December 14, 2015

Abstract: A pot experiment was conducted to evaluate the response of selected species of mycorrhizae for root colonization and phosphorus uptake by maize in an alluvial soil. Of all the species of mycorrhizae taken under consideration, Glomus mosseae was found to perform better in terms of root colonization, number of spores, grain yield and phosphorus uptake. The maximum plant height $(28.5 \mathrm{~cm})$, shoot dry weight $\left(19.45 \mathrm{~g} \mathrm{plant}^{-1}\right)$ and root dry weight $\left(4.77 \mathrm{~g} \mathrm{plant}^{-1}\right)$ was also found with the application of $G$. mosseae. Its application significantly increased the root dry weight by 99.58 and $72.82 \%$ over application of $G$. intraradices and control respectively, and was at par with the application of $G$. coronatum and Gigaspora decipiens. Application of $G$. decipiens reported the highest bacterial $\left(39.11 \mathrm{cfu} \mathrm{g}^{-1}\right.$ soil) and fungal count (30.68 $\mathrm{cfu} \mathrm{g}^{-1}$ soil) that was found to be at par with application of G. mosseae. Application of G. mosseae significantly increased the actinomycetes population by 44.71 and $55.97 \%$ over application of a local mycorrhizal strain and control. Maximum dehydrogenase activity $\left(56.00 \mathrm{~g}^{-1} \mathrm{TPF} \mathrm{g}^{-1} 24 \mathrm{~h}^{-1}\right)$ and acid phosphatase activity $\left(0.299 \mathrm{mg} \mathrm{PNP} \mathrm{g}^{-1} \mathrm{~h}\right.$ $\left.{ }^{1}\right)$ and was also observed with application of G. mosseae, which in turn resulted in higher yield which was $27.28 \%$, $28.52 \%, 9.35$ and $11.7 \%$ more than $G$. intraradices, G. coronatum, G. decipiens and the local species respectively. G. mosseae inoculation proved to be effective in modifying the soil microbe population and community structure and also in enhancing the soil enzymatic activities and phosphorus uptake of the crop.

Keywords: Alluvial soil, Grain yield, Maize, Mycorrhiza, Phosphorus

\section{INTRODUCTION}

Mycorrhiza is a mutualistic symbiosis between certain groups of soil fungi and most plant root systems (Schubler et al., 2001 and Hata et al., 2010). The most publicized benefit of mycorrhiza is the improved growth rate which is mainly due to enhanced phosphorus (P) nutrition. Various mechanisms (e.g. exploration of large soil volume, faster movement of mycorrhizal hyphae and solublization of soil phosphorus) are responsible for increasing the uptake of phosphorus by mycorrhizal plants. Non-nutritional benefits to plants, such as changes in water relations, phytohormone levels, carbon assimilation, secretion of enzymes, increased microbial count in soil, etc. have also been reported, but they are difficult to interpret. Other important roles of mycorrhiza in ecosystems include nutrient cycling (Andrade et al., 1998).

Phosphorus is one of the major essential macronutrients which limit plant growth owing to its low bioavailability in soils (Feng et al., 2004). Improving plant acquisition of $\mathrm{P}$ from soil is an obvious alternative for the management of those low $\mathrm{P}$ soils (Zhu et al., 2003). It is commonly known that arbuscular mycorrhizae (AM), they act as a direct link between soil and roots, AM fungi help plants to capture water and nutrients (especially P) from the soil, and in return, the plant provides the fungus with relatively constant and ISSN : 0974-9411 (Print), 2231-5209 (Online) All Rights Reserved @ Applied and Natural Science Foundation www.ansfoundation.org direct access to carbohydrates (Smith and Read, 2008), which are translocated from their source to root tissue and on to fungal partners.

Soil enzymatic activities regulate the various indices of soil fertility, soil productivity and soil quality (Busto and Perez-Mateos, 1997). AM fungi can increase soil enzyme activities, such as phosphatase (Mar Vazquez et al., 2000), dehydrogenase, urease, protease and $\beta$ glucosidase (Caravaca et al., 2004). Mar Vázquez et al. (2000) reported mycorrhizal colonization induced qualitative changes in the microbial population and enzyme activities in the rhizosphere of maize plants. On the other hand, soil phosphatase and urease are closely related to the $\mathrm{P}$ and $\mathrm{N}$ nutrition of plants. Thus, the enhancement of soil enzyme activities is one of the physiological and biochemical mechanisms involved in a mycorrhization effect on plant mineral nutrition. Rao and Tak (2001) found that mycorrhizal fungal inoculation resulted in enhanced plant growth, total uptake of N, P and many other nutrients, activities of dehydrogenase, phosphatases and nitrogenase in the rhizosphere in gypsum mine spoil. Owing to the energy and cost-intensive manufacture of chemical fertilizers, use of microbial inoculants to supplement a part of phosphorus requirement has attained immense importance. To get maximum agricultural benefit, inoculation of the soil with suitable type of AM fungi is nec- 
essary. In view of the above-mentioned possibilities, a pot experiment was conducted for screening the VAM species with respect to their effect on the growth of maize plant and its nutrient acquisition.

\section{MATERIAL AND METHODS}

The present study was undertaken to screen the AM fungi for maize crop during the rabi season of 2013-14 with a promising var. DHM-117, at Bihar Agricultural University, Sabour, Bhagalpur, India. Inoculums of the five AM species viz., Glomus mosseae, Glomus coronatum, Glomus intraradices, Gigaspora decipiens and Gigaspora margarita were commercial products of The Energy Resource Institute (TERI), New Delhi, India. The products consisted of fragments of colonized roots and spores of AM fungi in a vermiculite substrate. One uncharacterized local inoculum (control) was collected from the maize and litchi farm of Bihar Agricultural University, Sabour. The substrate used for the experiment consisted of soil from the Bihar Agricultural University, research farm and river bed sand of the Ganges (w/w, 3:1). The soil was collected from the surface $(0-15 \mathrm{~cm})$ and passed through a $2.00 \mathrm{~mm}$ aperture sieve to remove roots and debris. The river bed sand was thoroughly washed with tap water to remove salt. The substrate mixture was completely sterilized by autoclaving over $1 \mathrm{hr}$ with stepwise increase in temperature till the centre reached $120^{\circ} \mathrm{C}$ (kept for 30 minutes). The substrate used for the pot experiment was loamy sand in texture, having a $\mathrm{pH}$ of 7.2 and EC of $0.22 \mathrm{dS} \mathrm{m}^{-1}$. The organic carbon content of the substrate was $0.56 \%$, and the available nitrogen, phosphorus and potassium content was found $180.77,25.89$ and $220.66 \mathrm{~kg} \mathrm{ha}^{-1}$, respectively.

Seeds were surface-sterilized by treatment with a $1: 1$ mixture of $\mathrm{H}_{2} \mathrm{O}_{2}$ and absolute ethanol for 2 minutes followed by a treatment with $0.05 \% \mathrm{HgCl}_{2}$ for $1 \mathrm{~min}$ ute. The sterilizing agents were drained aseptically, and the seeds were washed for 10-12 times in sterile distilled water to remove all traces of the chemicals. Earthen pots of $15 \mathrm{~cm}$ height and $30 \mathrm{~cm}$ diameter were filled with $10 \mathrm{~kg}$ of sterilized substrate. All AM species were maintained in the pots with five replications each. The following treatment structure was formulated for the study: $\mathrm{T}_{1}-G$. mosseae, $\mathrm{T}_{2-}-G$. coronatum, $\mathrm{T}_{3^{-}}$G. intraradices, $\mathrm{T}_{4^{-}}$G. decipiens, $\mathrm{T}_{5^{-}}$G. margarita, $\mathrm{T}_{6^{-}}$Local (uncharacterized inoculum) and $\mathrm{T}_{7^{-}}$ control (without inoculum). About $5 \mathrm{~g}$ of the AM inoculum source (containing and 8-10 spores $\mathrm{g}^{-1}$ ) was mixed with the upper $4 \mathrm{~cm}$ of the substrate in each pot. In each pot, 4 sterile seeds of maize (var. DHM 117) were planted. Once in every 15 days, each pot was treated with $20 \mathrm{ml}$ of Hoagland solution minus phosphate (Hoagland and Arnon, 1938). One plant from each pot was uprooted after 75 days of sowing. After measuring the shoot height they were kept in a hot air oven to dry at $105^{\circ} \mathrm{C}$ for 72 hours until they attained a constant weight.
Samples of roots of the plants with adhering soil were collected at 75 days after sowing (DAS). They were washed repeatedly with sterilized distilled water and fragmented into small segments of $1 \mathrm{~cm}$. The root segments were cleared in $10 \% \mathrm{KOH}$ and stained with $0.5 \%$ Trypane blue by the method given by Phillips and Hayman (1970). The stained bits were examined and the Arbuscular mycorrhizal colonization in the roots was recorded in terms of per cent root segments showing mycorrhiza formation. The population of AM spores in the rhizospheric soil was estimated by extracting the spores from the root by the washingsieving-decanting method of Gerdemann and Nicolson (1963). They were examined stereomicroscopically and population was computed in terms of number per $100 \mathrm{~g}$ of dry soil. Phosphorus concentration in straw and grain were determined by employing the vanadomolybdate yellow colour method given by Jackson (1973).

Rhizosphere samples were obtained by collecting the soil adhering to the roots. The $10 \mathrm{~g}$ of soil samples were placed in an Erlenmeyer flask containing $90 \mathrm{ml}$ of sterilized distilled water, and shaken for $30 \mathrm{~min}$. Ten-fold series dilutions were prepared, and appropriate dilutions were plated in specific media. For the isolation of bacteria, fungi and actinomycetes, the Plate Count Agar, Czapek-Dox Agar (Thom and Raper, 1945) and Kenknight and Munaier's Medium, respectively were used. The numbers of colony forming cells were determined in each plot by serial dilution pour plate method (Subba , 1986). The activities of three soil enzymes: dehydrogenase activity (Casida et al., 1964), acid phosphatase and alkaline phosphatase (Tabatabai and Bremner, 1969) were determined. Analysis of variance (ANOVA) was performed as described by Gomez and Gomez (1984) to determine the effects of various treatments. Critical difference $(C D)$ at $5 \%$ level of probability and $P$ values was used to examine differences among treatment means.

\section{RESULTS}

Colonization and number of spores: The occurrence and intensity of root colonization in maize are presented in table 1. All the five species including the local species of AM fungi colonized the roots of maize. The root colonization was significantly higher with inoculation of $G$. mosseae over all the given treatments. The treatment having application of G. coronatum significantly increased root colonization by $22.83,50.02,31.66$ and $195.23 \%$ and the number of spores per $100 \mathrm{~g}$ of soil by $30.94,24.66,42.52$ and $592.57 \%$ over $G$. intraradices, $G$. margarita, local and control, respectively. Similarly, G. decipiens significantly increased mycorrhizal infection in the root by 35.26, 18.71 and $175.00 \%$ more than $G$. margarita, local and control, respectively (Table 1). The maximum mycorrhiza infection (78\%) and number of spores (311.66 per $100 \mathrm{~g}$ of soil) were reported with 
Table 1. Effect of arbuscular mycorrhizal fungi on plant growth, colonization and spore formation under maize Rhizospheric soil at 75 DAS.

\begin{tabular}{lccccc}
\hline Treatment & $\begin{array}{c}\text { AM infection } \\
(\boldsymbol{\%})\end{array}$ & $\begin{array}{c}\text { Number of spore } \\
\left(\mathbf{1 0 0} \mathbf{~ g}^{-\mathbf{1}} \text { of soil) }\right.\end{array}$ & $\begin{array}{c}\text { Plant height } \\
(\mathbf{c m})\end{array}$ & $\begin{array}{c}\text { Shoot dry weight } \\
\left(\mathbf{g ~ p l a n t ~}^{\mathbf{1}}\right)\end{array}$ & $\begin{array}{c}\text { Root dry weight } \\
\left(\mathbf{g ~ p l a n t}^{-\mathbf{1}}\right)\end{array}$ \\
\hline G. mosseae & 78.00 & 311.66 & 28.50 & 19.45 & 4.77 \\
G. intraradices & 49.66 & 238.00 & 22.60 & 14.45 & 2.39 \\
G. coronatum & 61.00 & 301.66 & 24.80 & 16.98 & 4.66 \\
G. margarita & 40.66 & 250.00 & 20.16 & 13.98 & 3.07 \\
G. decipiens & 55.00 & 275.66 & 21.87 & 18.87 & 4.68 \\
Local & 46.33 & 221.66 & 22.67 & 13.44 & 3.99 \\
Control & 20.00 & 45.00 & 15.89 & 12.47 & 2.76 \\
SEm $( \pm)$ & 3.50 & 24.99 & 1.48 & 1.98 & 1.20 \\
C.D. $(\mathrm{P}=0.05)$ & 7.48 & 47.61 & 3.34 & 4.83 & 2.00 \\
\hline
\end{tabular}

Table 2. Effect of AM fungi on soil biological properties under maize rhizosphere at 75 DAS.

\begin{tabular}{|c|c|c|c|c|c|c|}
\hline Treatment & $\begin{array}{c}\text { Bacteria } \\
\left(\mathbf{c f u} \times 10^{-6}\right)\end{array}$ & $\begin{array}{l}\text { Actinomycetes } \\
\left(\mathbf{c f u} \times \mathbf{1 0}^{-6}\right)\end{array}$ & $\begin{array}{c}\text { Fungi } \\
\left(\text { cfu } \times 10^{-4}\right)\end{array}$ & $\begin{array}{c}\text { DHA } \\
\left(\mathrm{g} \mathrm{TPF}^{-1} 24 \mathrm{~h}^{-1}\right)\end{array}$ & 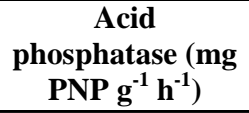 & 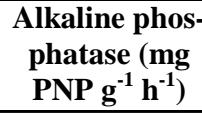 \\
\hline G. mosseae & 38.97 & 19.45 & 27.77 & 56.00 & 0.299 & 0.555 \\
\hline G. intraradices & 30.29 & 14.45 & 22.39 & 45.67 & 0.157 & 0.430 \\
\hline G. coronatum & 36.33 & 16.98 & 25.66 & 49.98 & 0.217 & 0.565 \\
\hline G. margarita & 33.66 & 13.98 & 16.07 & 39.75 & 0.248 & 0.433 \\
\hline G. decipiens & 39.11 & 18.87 & 30.68 & 44.87 & 0.31 & 0.546 \\
\hline Local & 30.29 & 13.44 & 18.99 & 39.76 & 0.205 & 0.457 \\
\hline Control & 15.89 & 12.47 & 11.76 & 12.67 & 0.101 & 0.201 \\
\hline $\operatorname{SEm}( \pm)$ & 1.48 & 1.98 & 3.39 & 2.88 & 0.035 & 0.05 \\
\hline C.D. $(\mathrm{P}=0.05)$ & 4.34 & 5.83 & 9.95 & 5.16 & 0.089 & 0.09 \\
\hline
\end{tabular}

Table 3. Response of maize to AM fungi for yield and yield attributes.

\begin{tabular}{lcccc}
\hline Treatment & $\begin{array}{c}\text { Number of cob } \\
\left(\text { plant }^{\mathbf{1}}\right)\end{array}$ & $\begin{array}{c}\text { Grain yield } \\
\left(\text { g plant }^{-\mathbf{1}}\right)\end{array}$ & $\begin{array}{c}\text { Biological yield } \\
\left(\mathbf{g ~ p l a n t}^{\mathbf{1}}\right)\end{array}$ & $\begin{array}{c}\text { 100-seed weight } \\
(\mathbf{g})\end{array}$ \\
\hline G. mosseae & 1.33 & 64.66 & 358.33 & 26.50 \\
G. intraradices & 1.33 & 50.8 & 315.33 & 23.00 \\
G. coronatum & 1.33 & 63.15 & 349.33 & 23.50 \\
G. margarita & 1.33 & 50.31 & 329.66 & 23.00 \\
G. decipiens & 1.00 & 59.13 & 330.66 & 25.07 \\
Local & 1.33 & 57.78 & 326.66 & 22.50 \\
Control & 1.00 & 46.86 & 281.33 & 22.00 \\
SEm $( \pm)$ & - & 9.80 & - & - \\
C.D. $(\mathrm{P}=0.05)$ & $\mathrm{NS}$ & 5.04 & $\mathrm{NS}$ & $\mathrm{NS}$ \\
\hline
\end{tabular}

application of G. mosseae. Application of G. decipiens significantly increased the number of spores by 24.06 and $512.57 \%$ over application of local strain of mycorrhiza and control. G. coronatum gave $26.4 \%$, $20.66 \%$ and $36.09 \%$ significantly higher number of spores than $G$. intraradices, G. margarita and local respectively. There is an absolute increase of 37 spores in case of Gigaspora decipiens, when we compare it with the number of $G$. intraradices (Table 1). Due to the favorable soil conditions for the development of $G$. mosseae, inoculation with Glomus mosseae gave significantly higher colonization as compared to $G$. intraradices, G. coronatum, G. margarita, G. decipiens and local.

Plant growth: Plant growth parameters like plant height $(\mathrm{cm})$, shoot dry weight $(\mathrm{g})$ and root dry weight increased with the inoculation of all the mycorrhiza fungi over non-inoculated control treatment. The maximum plant height $(28.5 \mathrm{~cm})$, shoot dry weight $(19.45 \mathrm{~g}$ plant $\left.^{-1}\right)$ and root dry weight (4.77 $\left.\mathrm{g} \mathrm{plant}^{-1}\right)$ was found with the application of $G$. mosseae. The application of
G. coronatum also gave 23.01 and $56.07 \%$ significantly higher plant height over inoculation of G. margarita and control. Plant height increased numerically by 12.10 and $3.33 \%$ with the application of $G$. intraradices over G. margarita and G. decipiens. Similarly, application of $G$. decipiens significantly increased shoot dry weight by $34.97,40.40$ and $51.32 \%$ over application of G. margarita, local and control, respectively (Table 1). A numerical increment of 17.50, $21.45,26.33$ and $36.16 \%$ was found in shoot dry weight when compared with application of $G$. intraradices, G. margarita, local and control, respectively. The application $G$. mosseae also significantly increased the root dry weight by 99.58 and $72.82 \%$ over application of $G$. intraradices and control and at par with $G$. coronatum and $G$. decipiens.

\section{Biological properties of rhizospheric soil}

Microbial population: All the applied mycorrhizal species increased the microbial population over control (Table 2). Application of $G$. decipiens gave signifi- 


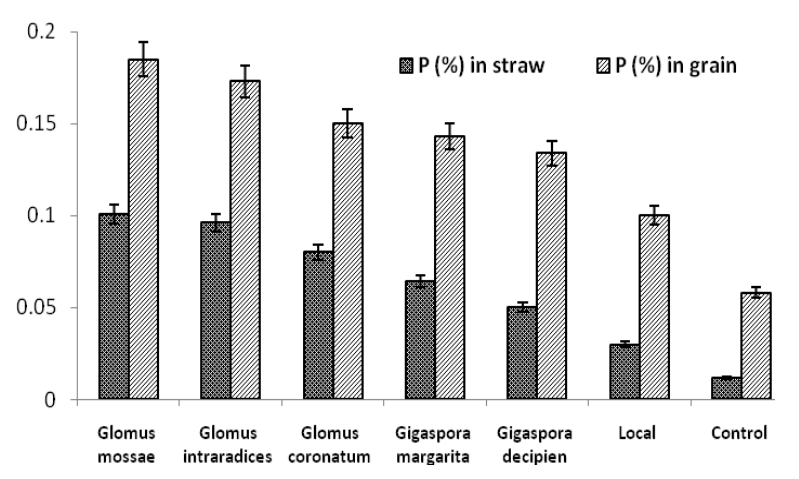

Fig. 1. a Effect of AM fungi on Phosphorus $(P)$ concentration.

cantly $29.11,16.19,29.11$ and $146.12 \%$ increased bacterial count over $G$. intraradices, $G$. margarita, local and control which is at par with the application of $G$. mosseae. Similar trend were observed in the population of fungi. Application of G. mosseae significantly increased the actinomycetes population by 44.71 and $55.97 \%$ over application of the local strain of mycorrhiza and control. Similarly application of $G$. decipiens significantly increased the actinomycetes population by $51.32 \%$ than control. The maximum fungi population (30.68 $\mathrm{cfu} \mathrm{g}^{-1}$ soil) was observed with application $G$. decipiens, which was $90.91,61.55$ and $160.88 \%$ over $G$. margarita, local and control, respectively. The fungi population was found significantly higher (118.19\%) with the application of G. coronatum over control. Similarly, G. mosseae also significantly increased the fungi population by 44.71 and $136.13 \%$ over G. margarita and control.

Soil enzymatic activity: The soil enzymatic activity was analyzed after 75 days of sowing and the results (Table 2) showed that there is an increment in enzymatic activity with application of mycorrhiza as compared to the control treatment. Maximum enzymatic activity viz. dehydrogenase activity (56.00 $\mathrm{g}^{-1} \mathrm{TPF} /$ $\mathrm{g} / 24 \mathrm{hrs}$ ) and acid phosphatase activity (0.299 mg $\mathrm{PNP} / \mathrm{g} \mathrm{h}$ ) and was observed with application of $G$. mosseae. The maximum alkaline phosphatase activity (0.565 mg PNP/g h) was found with application of $G$. coronatum. Application of $G$. coronatum significantly increased the alkaline phosphatase activity by 9.43 , 25.73 and $294.47 \%$ and Dehydrogenase activity by $31.39,30.48$ and $181.09 \%$ over application of $G$. intraradices, $G$. margarita and control respectively. Similarly, application of $G$. mosseae significantly increased the acid phosphatase activity by $90.44,45.85$ and $196.03 \%$ and alkaline phosphatase activity by 29.06 , 21.44 and $176.11 \%$ over $G$. intraradices, local and control, respectively. Application of $G$. decipiens also gave significant increment by 26.97, 26.09 and $171.64 \%$ over $G$. intraradices, G. margarita and control. This treatment also significantly increased the acid phosphatase activity by $42.85,51.21$ and $206.93 \%$ over $G$. coronatum, local and control, respectively.

Phosphorus content and uptake by grain and straw $P$ content in grain and straw: The maximum concen-

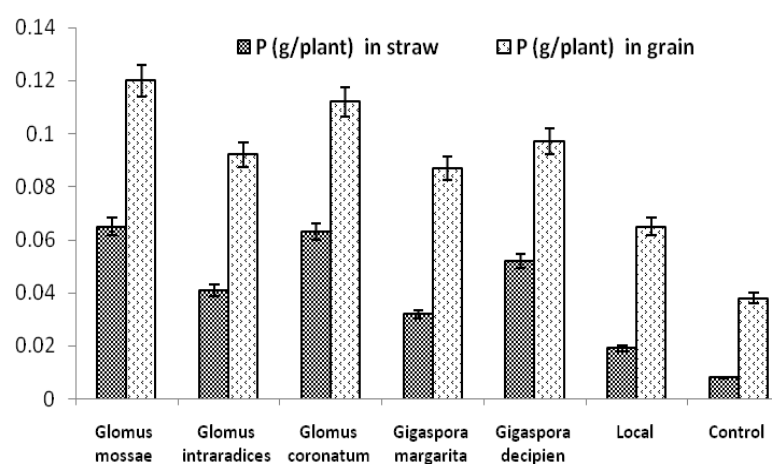

Fig. 1. b Effect of AM fungi on P uptake by straw and grain.

tration of $\mathrm{P}$ in straw $(0.101 \%)$ and grain $(0.120 \%)$ was found with treatment of $G$. mosseae. This treatment also significantly increased the $\mathrm{P}$ content in straw and grain over all the treatments. Application of G. coronatum also significantly increased $\mathrm{P}$ content in straw by $50,92,220$ and $700 \%$ over G. margarita, G. decipiens, local and control, respectively (Fig. 1a). The similar trend was observed for P content in grain. Application of $G$. intraradices significantly increased $\mathrm{P}$ content in grain by 73 and $198.27 \%$ over local and control. Similarly, application of $G$. coronatum also numerically increased the $\mathrm{P}$ content in grain by 4.89 , 11.94, 50 and $158.62 \%$ over G. margarita, $G$. decipiens, local and control, respectively.

$P$ uptake in grain and straw: Higher $\mathrm{P}$ uptake was recorded with the application of $G$. mosseae, in both straw (0.065 g plant $\left.{ }^{-1}\right)$ and grain $\left(0.12 \mathrm{~g} \mathrm{plant}^{-1}\right)$ (Fig. 1b). However, G. coronatum was quite competitive with $G$. mosseae with respect to the uptake of $\mathrm{P}$ in straw and grain. G. mosseae also gave significantly higher P uptake by straw in comparison with all treatments except $G$. coronatum. Application of $G$. coronatum significantly increased $\mathrm{P}$ uptake in straw by 53.65, 96.87, 21.14 and $231.57 \%$ more than $G$. intraradices, $G$. margarita, $G$. decipiens and local, respectively. A similar trend was observed in the uptake of $\mathrm{P}$ by grain. Application of $G$. decipiens significantly increased straw-P uptake by 62.5 , 173.68 and $550 \%$ over G. margarita, local and control, respectively. Similarly, application of $G$. decipiens numerically increased the grain-P uptake by $11.49,49.23$ and $155.26 \%$ over application of G. margarita, local and control respectively.

\section{Yield and yield attributes}

Number of cobs per plant: The treatments did not differ significantly from each other for the number of cobs per plant (Table 3). However, higher cobs per plant were recorded by the application of $G$. mosseae, G. intraradices, G. coronatum, G. margarita and $G$. decipiens.

Grain yield: Grain yield was found to be higher in the plants or seeds inoculated with G. mosseae (64.66 g plant $\left.^{-1}\right)$. Grain yield of maize plants followed the order: $G$. mosseae > G. coronatum > G. decipiens $>$ local $>$ G. intraradices. G. mosseae gave 27.28, 28.52, 9.35 and $11.7 \%$ more grain yield than application of $G$. in- 
traradices, G. coronatum, G. decipiens and local, respectively (Table 3). G. decipiens produced significantly higher yield by 16.39 and $17.53 \%$ than $G$. intraradices and $G$. margarita, respectively. Yield of grains in plants inoculated with $G$. coronatum was found to be at par with the yield obtained with the application of $G$. mosseae as well as with G. decipiens.

Biological yield: Biological yield was not affected significantly by any of the applied treatments. However the highest biological yield (358.33 $\mathrm{g}$ plant $^{-1}$ ) was recorded with the application of $G$. mosseae. Biological yield obtained with the application of local inoculum was $326.66 \mathrm{~g} \mathrm{plant}^{-1}$, which is quite competitive with others. Application of $G$. coronatum numerically increased the biological yield by $10.79,5.96,4.23$, 6.93 and $24.17 \%$ over treatments having $G$. intraradices, G. margarita, G. decipiens and local, respectively. 100-seed weight: The treatments did not differ significantly from each other for the 100-seed weight (Table 4). However the highest 100 -seed weight (26.50 g) was recorded with the application of $G$. mosseae. Application of $G$. decipiens increased the 100 -seed weight by $9.00,6.68,9.00,11.42$ and $13.95 \%$ over $G$. intraradices, G. coronatum, G. margarita, local and control respectively (Table 3 ).

\section{DISCUSSION}

Colonization and spore: Higher root colonization was significantly observed in maize after inoculation with G. species. Mycorrhizal fungi differ in their ability to infect and colonize roots. Glomus species has ability to infect and colonize plant roots faster than Gigaspora species, making it highly competitive (Kurle and Pfleger, 1994). The higher mycorrhizal colonization in maize could be due to strigolactones exuded by host plant roots and taken up by AMF since strigolactones stimulate fungal metabolism and branching (Parniske, 2008). Successful colonization and functional interaction between host plant and the mycobiont is based on the exchange of signaling molecules at different stages of symbiosis. The role of strigolactones as the key signaling compounds in the interaction between plants and soil-borne symbiotic AMF has been suggested recently (Soto et al., 2010).

Plant growth: Significant differences $(\mathrm{p} \leq 0.05)$ were detected for plant height, shoot dry weight and root dry weight among all treatments as well as when the six mycorrhizal inoculants were analyzed separately. It might be due to AM fungi which increased nutrient acquisition from an organic fertilizer source by enhancing root acid phosphatase (ACP) and alkaline phosphatase (ALP) activity thus facilitating $\mathrm{P}$ acquisition, increasing photosynthesis, and improving plant growth (Carpio et al., 2009). AMF promotes plant growth by bringing morpho-physiological and biochemical changes in host plants. AMF causes modification in root morphology so as to mediate water and mineral uptake (Alqarawi et al., 2014; Abeer et al.,
2015). The G. mosseae isolate provided the highest improvement with respect to the plant height, shoot dry weight and root dry weight of maize plant. G. margarita provided significantly less growth benefit than $G$. coronatum, G. mosseae and $G$. decipiens isolates. Results presented in Table 1 indicate that different isolates of the same genus may be distinct in their interaction with the same plant types. Isolates from the genus Glomus provided consistently greater growth benefit than the genus Gigaspora as well as the uncharacterized inoculum cultured from the litchi orchard soil used in the experiment. It may be justified by the fact that the inoculation of VAM enhanced the mitotic activity of stem cells resulting in taller plants and more availability of phosphorus for absorption by roots. The different genera of mycorrhiza isolates differ in the production of strigolactones which are a novel class of phytohormones involved in the regulation of shoot branching in plants and are secreted by plant roots for stimulating the presymbiotic growth of AMF. With the identification of strigolactones as the branching factor, not only its production, exudation into the rhizosphere and perception by the AMF but also its specific action in arbuscular mycorrhizal symbiosis (AMS) can now be explored in detail (Bucher et al., 2009).

Microbial soil properties: Root structure and functions change due to mycorrhizal infection. Possible VAM induced changes in root exudates and the rhizosphere population, as well as possible physical barriers and chemical inhibitors from AM fungi may have practical implications in the biological control of some plant disease causing organisms. In addition to stimulating Rhizobium, VA mycorrhiza also influences rhizospheric bacteria beneficial to the plant. Some bacteria survive for a longer time under mycorrhizal infection than in non-mycorrhizal plants. Similarly, after colonization on plant roots with AM fungi, the quantity of rhizospheric microbes significantly increased (John, 2001). The number of both rhizospheric bacteria and actinomycetes enhanced when plant formed mycorrhizae, while the dominant species composition also changed (Secilia and Bagyaraj, 1987). There may be two pathways for AM fungi to change microbe community structure, the first one is that the AM fungal hypha secretion directly impacts microbe community structures; the another one is that both AM fungi in roots and on the roots alter plant physiological and biochemical processes, then directly or indirectly change the plant root secretion (Badri and Vivanco, 2009), thus alter those structures (Zhu et al., 2005).

In this experiment, we further observed that activities of soil dehydrogenase, acid phosphatase and alkaline phosphatase in maize rhizospheric soils gradually increased when compared with control. It might be due to inoculation with AM fungi enrich soil microbe quantities, equilibrate proportion of various microbes, maintain a stabilization of proper proportion of the microbes, enhance soil carbon, nitrogen, and phosphorous cycling power, thus improve the soil enzyme ac- 
tivity. Our results of increased activities of alkaline and acidic phosphatases in AMF inoculated plants. The similar type of findings was reported in Fraxinus rotundifolia (Kebradadi et al., 2014), Ipomoea carnea (Amaya et al., 2009), and Chrysanthemum indicum (Prasad et al., 2012). Sunflower under cadmium (Cd) stress, $\mathrm{Cd}$ reduced the plant photosynthesis rate, growth, chlorophyll contents and cell membrane stability whereas, in AMF inoculated plants showed higher activities of acid and alkaline phosphatases which improved the plant growth, photosynthesis rate and cell membrane stability and reduced the Cd stress (Allah et al., 2015). Gianinazzi et al. (1979) suggested that ALP production in mature intra-radical arbuscules led to polyphosphate breakdown. ACP can enhance release of inorganic phosphorus from organophosphates.

$P$ content in straw and grain: Phosphorus content in straw and grain was found to be highest under $G$. mosseae inoculation (Fig.1a). It might be due to the solubilization of unavailable phosphorus and increase in phosphorus uptake through plants root since mycorrhiza is responsible for increase in the surface area of roots. About $95-99 \%$ of the total $\mathrm{P}$ in soil exists in insoluble form unavailable to plants. The remaining soluble $\mathrm{P}$ is mostly present on exchangeable sites in equilibrium with the small amount of $\mathrm{P}$ in the soil solution. Therefore any solubilization of insoluble $\mathrm{P}$ by AM fungi significantly adds to the available pool. These results corroborate with the results of Gui et al. (2011) who reported that inoculation of G. mosseae significantly increased plant $\mathrm{P}$ concentration over uninoculated maize plants.

P uptake: P uptake was found to be higher with the application of $G$. mosseae, than $G$. coronatum and $G$. decipiens (Fig.1b). AMF induced enhancement in phosphatase activity could possibly mediate the release of organically bound phosphorous and hence increasing transport and uptake of phosphorous in AMF inoculated plants. Increased activity of phosphatases has direct bearing with the phosphorus metabolism. Bhadraiah et al. (1999) observed a high degree of correlation between phosphorous uptake and activity of phosphatases. Earlier studies by Bethlenfalvay (1993) also show that different species and strains of AMF differ in their effectiveness in increasing nutrient uptake and plant growth. The pattern of extra- and intra-radical forms of AMF hyphae can also justify the difference in phosphorus acquisition among the AMF isolates. Hence, the level of development of extra-radical mycelium in the soil is a major determinant of the efficiency of AMF for phosphorus uptake (Rakshit and Bhadoria, 2009). Similar results indicating that phosphorus uptake by mycorrhizal plants fluctuate with fungal isolates and genetic variability; have also been found on soybean cultivars (Diop et al., 2003). The nitrogen and phosphorus transfer to the maize plants may also be a consequence of the competitive demand for the nutrients, with both host plant and fungus evolving transporters to take advantage of the localized increase in nutrients.
Yield: The yield and yield attributes increased significantly over control with the inoculation of AM species. Studies conducted by Sabia et al. (2015) also revealed a significant effect of AM inoculation on dry matter yield and quality of forage maize cultivated within a low input system. This might be due to enhanced nutrient uptake by the roots. Since immobile ions in soil like phosphate lead to formation of a zone of phosphate depletion around roots in phosphate deficient soils mycorrhizal growth helps the roots to absorb phosphate ions much faster which are replenished at the root surface by diffusion. The AM hyphae attached to the roots extend beyond this depletion zone and promote nutrient translocation from the soil to the plants through the root cortex.

\section{Conclusion}

The inoculation with AM fungus enhanced the population of soil bacteria, fungi and actinomycetes and also improved soil dehydrogenase, acid phosphatase and alkaline phosphatase activities as compared to the control. It also contributed to relative better plant growth and higher uptake of phosphorus. As evident from the results, the AM fungal inoculation can effectively modify the soil microbe population and community structure by increasing the soil enzymatic activities and plant phosphorus uptake.

\section{ACKNOWLEDGEMENT}

This work is a part of an ongoing research project "Evolution of AM fungi on phosphorus dynamics under maize rhizospheric soil" which is financially supported by the Bihar Agricultural University, Bihar, India.

\section{REFERENCES}

Abeer, H., Allah, E.F.A., Alqarawi, A.A., Al-Whibi, M., S. Alenazi, M.M., Egamberdieva, D. and Ahmad, P. Ahmad. (2015). Arbuscular mycorrhizal fungi mitigates $\mathrm{NaCl}$ adverse effects on Solanum lycopersicum L. Pak. J. Bot. 47(1):327-340.

Allah, E.F.A., Abeer, H., Alqarawi, A.A. and Hend, A.A. (2015). Alleviation of adverse impact of cadmium stress in sunflower (Helianthus annuus L.) by arbuscular mycorrhizal fungi. Pak. J. Bot. 47(2): 785-795.

Alqarawi, A.A., Allah, E.F.A. and Abeer, H. (2014). Alleviation of salt-induced adverse impact via mycorrhizal fungi in Ephedra aphylla Forssk. J. Plant Interact. 9 (1):802-810.

Amaya C., L., Davies, F.T., Fox, T. and He, C. (2009). Arbuscular mycorrhizal fungi and organic fertilizer influence photosynthesis, root phosphatase activity, nutrition, and growth of Ipomoea carnea ssp. Fistulosa. Photosynthetica 47 (1): 1-10.

Andrade, G., Linderman, R.G. and Bethlenfalvay, G.J. (1998). Bacterial associations with the mycorrhizosphere and hyphosphere of the arbuscular mycorrhizal fungus Glomus mosseae. Plant Soil. 202: 79-87.

Badri, D.V. and Vivanco, J.M. (2009). Regulation and function of root exudates. Plant Cell Environ. 32(6):666-681. 
Bethlenfalvay, G.J. (1993). Mycorrhizae in the agricultural plant-soil system. Symbiosis 14(1-3): 413-414.

Bhadraiah, B., Kankadurga, V.V. Kankadurga, Ramrao, P. Ramrao and Manoharachary C. (1999). Effect of VAM fungi and rock phosphate on phosphatase activities in Terminalia arjuna. National Conference on Mycorrhiza Section. Physiol Biochem. 5-7.

Bucher, M., Wegmuller, S. and Drissner, D. (2009). Chasing the structures of small molecules in arbuscular mycorrhizal signaling. Curr. Opin. Plant Biol. 12: 500-507.

Busto, M. D. and Perez-Mateos, M. (1997). Stabilisation of cellulases by cross-linking with glutaraldehyde and soil humates Extraction of humic-fl-glucosidase fractions from soil. Biores Technol. 60: 27-33.

Caravaca, F., Alguacil, M.M., Azcon, R., Díaz, G., Roldan, A. (2004). Comparing the effectiveness of mycorrhizal inoculation and amendment with sugar beet, rock phosphate and Aspergillus niger to enhance field performance of the leguminous shrub Dorycnium pentaphyllum L. Appl. Soil Ecol. 25: 169-180.

Carpio, A. L., Davies, F.T., Fox, T. and He, C. (2009). Arbuscular mycorrhizal fungi and organic fertilizer influence photosynthesis, root phosphatase activity, nutrition, and growth of Ipomoea carnea ssp. Fistulosa. Photosynthetica 47 (1): 1-10.

Casida, L.E., Klein, D.A. and Santoro, T. (1964). Soil dehydrogenase activity. Soil Sci., 98:371-376.

Diop, T. A., Krasova-Wade, T., Diallo, A., Diouf, M. and Gueye, M. (2003). Solanum cultivar responses to arbuscular mycorrhizal fungi: growth and mineral status. Afr. J. Biotech., 2(11): 429-433.

Feng, K., Lu, H. M., Sheng, H. J., Wang, X. L. and Mao, J. (2004). Effect of organic ligands on biological availability of inorganic phosphorus in soils. Pedosphere 14: 85-92.

Gerdemann, J.W. and Nicolson, T.H. (1963). Spores of mycorrhizal Endogone species extracted from soil by wetsieving and decanting. Trans. Br. Mycol. Soc. 46: 235-244.

Gianinazzi, S., Gianinazzi, V. and Pearson, J. (1979). Dexheimer, Enzymatic studies on the metabolism of vesicular-arbuscular mycorrhiza. III. Ultrastructural localization of acid and alkaline phosphatase in onion roots infected by Glomus mosseae (Nicol. \& Gerd.), New Phytol. 82: 127-132.

Gomez, K.A. and Gomez, A.A. (1984) Statistical Procedures in Agricultural Research. Wiley Publishing House, New York

Gui,Y. Z., Li, P. Z., Ming, F. W., Zhen, L., Qiao, L. F., Qi, R. S. and Guo. H. Xu. (2011). Effect of arbuscular mycorrhizal fungi, organic fertilizer and soil sterilization on maize growth. Acta Ecologica Sinica 31:192-196.

Hata, S., Kobae, Y. and Banba, M. (2010). Interactions between plants and arbuscular mycorrhizal fungi. Int. Rev. Cell Mol. Biol. 281: 1-48.

Hoagland, D.R. and Arnon, D.I. (1938). The water culture method of growing plants without soil. California Agricultural Experiment Station, Circ. 347.

Jackson, M. L. (1973). Soil Chemical Analysis. Prentice Hall, New Delhi, 32, 34-36..

John, M. (2001). Microbial interactions and biocontrol in the rhizosphere. J. Experimental. Bot. 552 (1):487-511.

Kebrabadi, B.Z., Matinizadeh, M., Daryayi, M.G., and Salehi, A. (2014). Changes in acid and alkaline phosphatase enzyme activity in rhizosphere ash Fraxinus rotundifolia and its correlation with soil and plant phosphorus. J. Biodiversity Environ Sci. 4(5): 233-238.
Kurle, J. E. and Pfleger, F.L. (1994). The effect of cultural practices and pesticides on VAM fungi. In: F.L. Pfleger and R.G. Linderman (Eds.) Mycorrhizae and Plant Health. APS Press, Minnesota, pp. 101-131.

Mar Vazquez, M., Cesar S., Azcon R., Barea, J.M. (2000). Interactions between arbuscular mycorrhizal fungi and other microbial inoculants (Azospirillum, Pseudomonas, Trichoderma) and their effects on microbial population and enzyme activities in the rhizosphere of maize plants. Appl. Soil Ecol. 15:261-272.

Parniske, M. (2008). Arbuscular mycorrhiza: the mother of plant root endosymbioses, Nature Rev. Microb. 6: 763775.

Philips, J.M. and Hayman, D.S. (1970). Improved procedures for clearing roots and staining parasitic and vesiculararbuscular mycorrhizal fungi for rapid assessment of infection. Trans Br Mycol Soc. 55: 158-161.

Prasad, K., Yadav A., Aggarwal K. and Tanwar, A. (2012). Impact of different levels of superphosphate using arbuscular mycorrhizal fungi and Pseudomonas fluorescens on Chrysanthemum indicum L. J. Soil Sci. Plant Nut. 12(3): 451-462.

Rakshit, A. and Bhadoria, P. (2009). Influence of arbuscular mycorrhizal hyphal length on simulation of $\mathrm{P}$ influx with the mechanistic model, Afr. J. Microb. Res. 3 (1): 001-004.

Rao, A.V., Tak, R. (2001). Influence of mycorrhizal fungi on the growth of different tree species and their nutrient uptake in gypsum mine spoil in India. Appl. Soil Ecol. 17: 279-284.

Sabia, E., Claps, S., Morone, G., Bruno,A., Sepe, L. and Aleandri, R. (2015). Field inoculation of arbuscular mycorrhiza on maize (Zea mays L.) under low inputs: preliminary study on quantitative and qualitative aspects. Italian J. Agron. 10: 30-33.

Schubler, A., Schwartzott, D. and Walker, C. (2001). A new fungal phylum, the Glomeromycota: phylogeny and evolution. Mycological Res. 105: 1413-1421.

Secilia, J. and Bagyaraj, D.J. (1987). Bacteria and actinomycetes associated with pot cultures of vesicular arbuscular mycorrhizas. Canadian J. Microbial. 33(8):1069-1073.

Smith, S.E. and Read, D.J. (2008). Mycorrhizal symbiosis. Academic Press, London, UK.

Soto, M.J., Fernaández-Aparicio, M., Castellanos-Morales, V., García-Garrido, J.M., Ocampo, J.A., Delgado, M.J. and Vierheilig, H. (2010). First indications for the involvement of trigolactones on nodule formation in alfalfa (Medicago sativa). Soil Biol. Biochem. 42: 383-385.

Subba, R.N.S. (1986). Rhizobium and root nodulation. In: soil microorganisms and plant growth. Oxford IBH New Delhi.

Tabatabai, M.A. and Bremner, J.M. (1969). Use of pnitrophenyl phosphate for assay of phosphatase activity. Soil Bio Biochem. 1:301-307.

Thom, C. and Raper, K.B. (1945). A manual of the Aspergilli. Williams and Wilkins Co., Baltimore, U. S. A.

Zhu, H.H., Long, L.K. and Yang, S.Z. (2005). Influence of AM fungus on Ralstonia Solanacearum Population and bacterial community structure in rhizosphere. Mycosystema 24(11):137-142.

Zhu, Y.G., Smith, F.A. and Smith, S.E. (2003). Phosphorus efficiencies and responses of barley (Hordeum vulgare L.) to arbuscular mycorrhizal fungi grown in highly calcareous soil. Mycorrhiza. 13:93-100. 